\title{
Composition of coral species and benthic organism at Tiaka Oilfield, Tolo Bay, Central Sulawesi
}

\author{
Kasim Mansyur ${ }^{1 *}$, Achmad Rizal ${ }^{1}$, Musayyadah Tis'in ${ }^{1}$, Muh. Saleh Nurdin ${ }^{1}$, Nuke Susanti ${ }^{2}$ \\ ${ }^{1}$ Marine Research Center and Coastal Community Empowerment, Tadulako University, Indonesia. \\ ${ }^{2}$ Joint Operating Body, Pertamina-Medco Tomori Sulawesi, Indonesia. \\ *Corresponding author: kasim.mansyur@untad.ac.id
}

\section{ARTICLE INFO}

\section{Keywords:}

Benthic organism; Coral species; Tiaka Oilfield.

\section{How to cite:}

Mansyur, K., Rizal, A., Tis'in, M., Nurdin, M. S., \& Susanti, N. (2020). Composition of coral species and benthic organism at Tiaka Oilfield, Tolo Bay, Central Sulawesi. Tomini Journal of Aquatic Science, 1(1), 22-28

\begin{abstract}
This research aims to find out the composition of the coral and benthic organisms at Tiaka Oilfield as providing a baseline for management and conservation. This study was conducted in July 2015. Monitoring of coral and benthic organisms used line intercept transect and visual census method. The research results indicated that 16 coral species were consisting of 6 genera. Coral species dominated by the genus Acropora. Benthic organisms that live in symbiosis with coral reef ecosystems in Tiaka Oilfield were found 11 benthic species consisting of 54 species.
\end{abstract}

\section{INTRODUCTION}

Tiaka Field is an offshore oilfield operated on an artificial island (Gosong Tiaka) (Tis'in \& Mansyur, 2016; Mansyur et al., 2019). According to the results of seismic calculations, the oil reserves in the field reach seven million barrels with crude oil production of 3,500 barrels per day at the beginning of production (Lampe, 2018). Since the Tiaka Oilfield is in operation, it is predicted to potentially affecting the degradation of coral reef ecosystems and the associated biota. The degradation of coral reefs in Gosong Tiaka occurred due to the impact of the activities of the development of artificial islands in 2003-2005 (Syakir et al., 2015).

According to Sukmara et al. (2001), corals are massive deposits of calcium carbonate (lime) produced by coral animals with the ministrations of calcareous algae and other calcium carbonate-producing organisms (Westmacott et al., 2000; Woodley et al., 2003; Insafitri \& Nugraha, 2006; Ammar et al., 2013; Faqih et al., 2016). Coral animals are classified into the Cnidaria phylum, Anthozoa class, order Scleractinia (Sukmara et al., 2001; Burke et al., 2002; Suharsono, 2008). In Indonesia, there were approximately 82 genera with 569 coral species (Suharsono, 2008; Giyanto et al., 2017).

Coral reef ecosystems have an essential role, both in ecological and socio-economic aspects (Yunus et al., 2013; Manembu et al., 2014; Ramadhan et al., 2016). Ecologically, coral reefs are habitat for many marine biotas, which are a source of biodiversity (Hadi et al., 2018). Also, coral reefs function as a spawning ground, feeding ground, and nursery ground for marine biota 
(Souhoka, 2009). Therefore the excellent reef conditions can upturn fisheries' productivity. Increasing the productivity of coral reefs and the diversity of biota that exists in coral reef ecosystems can attract the attention and interest of tourists, which ultimately supports regional development and increased incomes from the tourism sector. In line with that, the better the ecosystem environment, the more fisheries production can be improved (Harahap et al., 2017).

Declining conditions on coral reefs will have an impact on underwater life due to the interdependence of one another. In addition, it can also eliminate the important function of coral reefs as a barrier to abrasion in coastal areas (Wijaya et al., 2017; Zhao et al., 2019). At present, there has been a decline in the condition of coral reefs in 93 countries, including Indonesia (Arini, 2013). One of the waters in Indonesia which has experienced deterioration in coral reef conditions is Tolo Bay. Besides artificial island development activities (Syakir et al., 2015), the decline in the condition of coral reef ecosystems in Tolo Bay is also caused by an abundance of the crown of thorns starfish Achantaster planci (Mansyur et al., 2019). Other causes are human activities (Edrus et al., 2010; Renfro and Chadwick, 2017; Camp et al., 2018) such as the use of eco-unfriendly fishing gear such as the use of fishing bombs (fishing blasting), random disposal of boat/boat anchors over coral reef areas, pollution, and sedimentation and even massive harvesting of coral reefs (Santoso \& Kardono, 2008; Babu \& Sureshkumar, 2016; Tis'in \& Mansyur, 2016; Lutfi, 2016; Muliawan \& Firdaus, 2018). A coral reef management activity is needed to prevent further coral damage. Studies are needed relating to coral and biota resources in it before carrying out management (Jimenez et al., 2010).

Therefore, it is necessary to conduct research related to the composition of coral species and benthic organisms found in the Tiaka Oilfield, Tolo Bay. This research is expected to be a source of information about coral species and benthic at Tiaka Oilfield.

\section{MATERIAL AND METHODS}

Study site. The research was conducted in June 2015. The research location is located in the waters of the Tiaka Oilfield, Senoro-Toili Block, Central Sulawesi Province. Tiaka Field is an offshore oilfield that is operated on an artificial island (Gosong Tiaka). This location is in the waters of the Gulf of Tolo with the nearest land distance of about 12 nautical miles. The exact location of the study is at coordinates S 01050'10.3", E 121059"06.2", located $\pm 586 \mathrm{~m}$ from the Tiaka Field at a depth of 5-6 m above sea level at the lowest ebb (Figure 1).

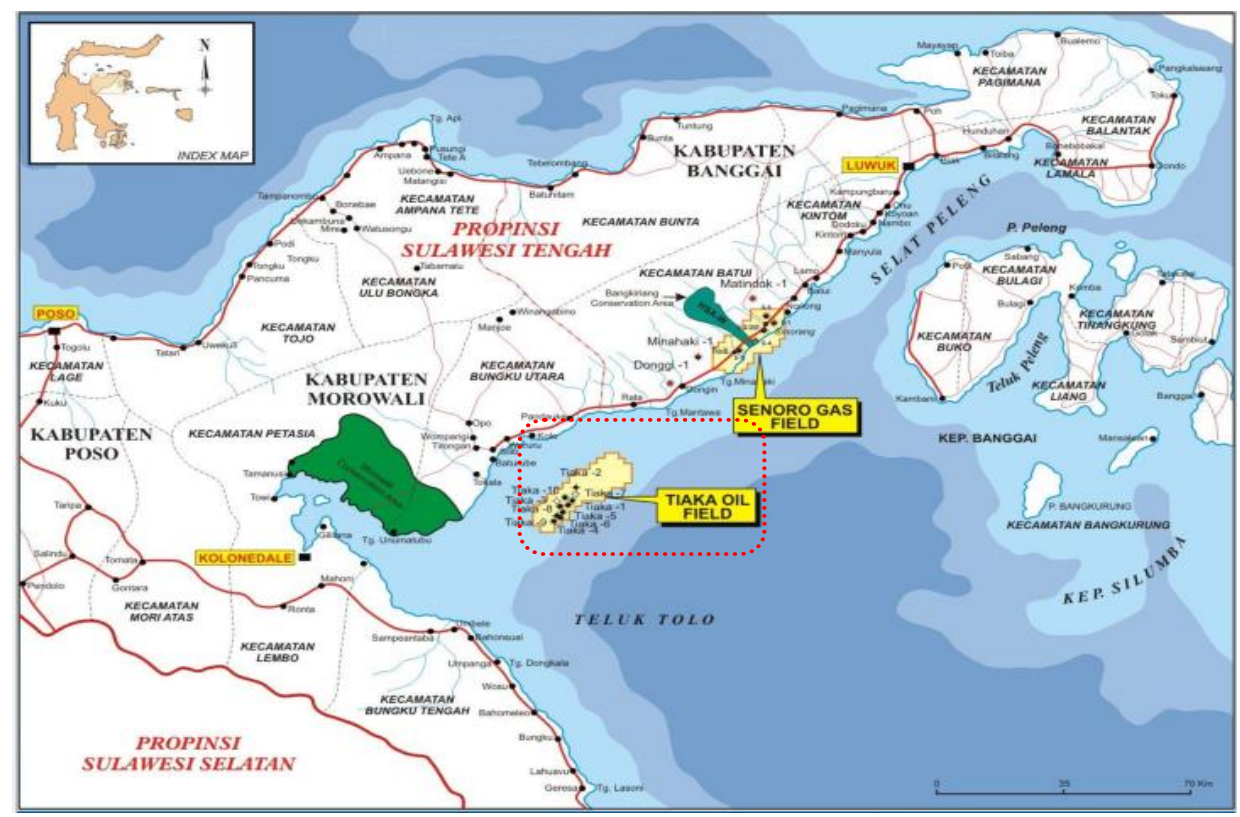

Figure 1. Study area 
Procedures. Monitoring the composition of coral and benthic species using the line intercept transect method and visual census (Gomez \& Yap, 1998; English et al., 1997). In the identification of coral species, the primary data are the results of photographs of corals and a book identification of coral forms by Suharsono (2008). The coral composition and benthic survey procedures are generally described as follows: (1) $100 \mathrm{~m}$ transect installation; (2) Identification is carried out after 3 to 5 minutes after transect installation; (3) Census along the transect was conducted using SCUBA equipment with an observation distance of $2.5 \mathrm{~m}$ to the left and right; (4) Seeing the shape of coral growth from photo results, once finding out the growth form is then matched with the identification book and (5) The observations are then recorded on the worksheet.

\section{RESULTS AND DISCUSSION}

Composition of coral species. The results showed that there were 16 coral species spread in 6 genera. The 16 species are Acropora formosa, Acropora nobilis, Acropora nasuta, Acropora grandis, Acropora secale, Acropora digitifera, Acropora palifera, Acropora echinata, Acropora donei, Acropora cutais, Palauastrea ramosa, Montipora digitale, Acropora digitifera, Acropora palifera, Acropora echinata, Acropora donei, Acropora cerealis, Palauastrea ramosa, Montipora digitale, Acropora digitifera, Acropora palifera, Acropora echinata, Acropora donei, Acropora cerealis, Palauastrea ramosa, Montipora digitata, Acropora digitifera, Acropora palifera, Acropora echinata, Acropora donei, Acropora cerealis, Palauastrea ramosa and Psammocora contigua. Among the 16 species, there are three of the most dominant coral species found, namely $A$. formosa, A. nobilis, and A. grandis. The Acropora genus in the Tiaka Oilfield is dominated by tabulate and corymbosa forms, especially those that grow on reef flat and reef crest areas (Syakir et al., 2015). This type of coral has a relatively fast growth compared to other types of coral (Anderson et al., 2012; Fadli et al., 2019) this is due to the skeletal structure of Acropora coral is more porous (Rani et al., 2017), therefore, it is suitable to be applied in the rehabilitation of coral reefs (Mansyur et al., 2019).

The composition of coral species found in the Tiaka Oilfield is equal that found in the Papayago Bay of Costa Rica (16 species) (Jimenez et al., 2010) yet less than those found by Souhoka (2009) on Nusalaut Island, Central Maluku (123 species) and Northeast of Hainan Island, South China Sea (39 species) (Zhao et al., 2019) and in Pulau Dua waters, North Bengkulu Regency (24 species) (Muqsit et al., 2016). In this study, the most dominant coral species found were Acropora corals in 9 species. Acropora coral species in the world there are about 113 species and 91 species of Acropora in Indonesia alone (Suharsono, 2008). Togean Island is the most dominant area of 78 species of Acropora corals, including the Togean endemic coral species, namely Acropora togeanensis (Khazali, 2007). According to Fadli et al. (2019), corals of the Acropora genus are types of corals that require very high levels of water brightness and a constantly moving water mass (Panggabean and Setiadji, 2011). This is what underlies so that the Acropora genus is very dominant in the Tiaka Oilfield as its geographical location far from the main land causes high water brightness (100\%) and supports the fulfillment of light requirements for the zooxanthella photosynthesis process (Syakir et al., 2015; Mansyur et al., 2019).

Benthic organisms. The results of benthic biota studies that live in symbiosis with coral reef ecosystems in the Tiaka Oilfield found 11 benthic species consisting of 54 species, as presented in Table 1.

Table 1. Benthic organisms

\begin{tabular}{ll}
\hline Benthic types & Species \\
\hline Tridachnidae & Tridacna maxima \\
& Tridacna squamosa \\
Seashells & Tridacna crocea \\
& Dendropoma maxima \\
\hline
\end{tabular}




\begin{tabular}{|c|c|}
\hline Benthic types & Species \\
\hline & Tetrus niloticus \\
\hline \multirow{3}{*}{ Sea urchin } & Diadema setosum \\
\hline & Stomopneustes variolaris \\
\hline & Phyllacanthus imperalis \\
\hline \multirow[t]{4}{*}{ Starfish/Asteroidea } & Linckia laevigata \\
\hline & Culcita novaguineae \\
\hline & Culcita sp. \\
\hline & Acanthaster plancii \\
\hline \multirow[t]{6}{*}{ Ascidian } & Didemnum molle \\
\hline & Diplosoma similis \\
\hline & Lissoclinum patella \\
\hline & Rhopalaea crassa \\
\hline & Polycarpa aurata \\
\hline & Pycnoclavella sp. \\
\hline \multirow[t]{4}{*}{ Anemones } & Macrodactyla doreensis \\
\hline & Stichodactyla haddoni \\
\hline & Stichodactyla gigantea \\
\hline & Stichodactyla martensii \\
\hline \multirow[t]{7}{*}{ Macroalgae } & Padina gymnospora \\
\hline & Turbinaria sp. \\
\hline & Amphiroa foliacea \\
\hline & Halimeda micronesia \\
\hline & Halimeda sp. \\
\hline & Valonia ventricosa \\
\hline & Titanophora weberae \\
\hline \multirow[t]{10}{*}{ Sponge } & Gelliodes sp. \\
\hline & Callyspongia sp. \\
\hline & Callyspongia muricina \\
\hline & Haliclona fascigera \\
\hline & Clathria basilana \\
\hline & Clathria reinwadsti \\
\hline & Lanthella sp. \\
\hline & Phakellia aruensis \\
\hline & Spirastella vagabunda \\
\hline & Hadromerida spirastrellidae \\
\hline \multirow[t]{5}{*}{ Comasteridae } & Stephanometra sp. \\
\hline & Camaster multifidus \\
\hline & Petasometra clarae \\
\hline & Comanthina audax \\
\hline & Oxycomanthus bennetti \\
\hline \multirow[t]{4}{*}{ Hydrozoans } & Aglaophenia cupressina \\
\hline & Plumularia sp. \\
\hline & Lytocarpus phillippinus \\
\hline & Aglaophenia sp. \\
\hline \multirow{5}{*}{ Soft coral } & Lobophyton sp. \\
\hline & Sinularia sp. \\
\hline & Sarcophyton sp. \\
\hline & Nepthea sp. \\
\hline & Xenia sp. \\
\hline
\end{tabular}

Benthic organisms found in this study were divided into two groups: animal groups and plant groups. Benthic animals are dominated by Anemones, Hydrozoans, Ascidians, and Sponges. The 
number of benthic animals found in the waters is alleged due to the proper physical. This water condition continually brings new nutrients in the water column (Bahri et al., 2015). Nevertheless, the significant object that must be a concern is the space competition between benthic and coral organisms. Specifically for Hydrozoans type Plumularia sp. and Ascidian Didemnum molle species are biofuoller organisms that are competitors for coral seedlings. Space competition between benthic organisms and corals depends on coral recruitment, which will ultimately have consequences for obstruction of coral reef growth (Ruswahyuni \& Purnomo, 2009; Mansyur et al., 2019). Additionally, the presence of several benthic animals such as bivalves, polychaeta, sponges, bryozoa, tunicates, algae-eating fish, and sea urchins can damage the structure of coral skeletons and reefs and change the trophic structure of coral reefs (Rani, 2007). According to Rani (2007), a weak reef structure can reduce resilience and coral growth to be slow so that it affects the decrease in the rate of recovery after bleaching events and other natural disturbances

\section{CONCLUSION}

There are 16 species of coral found in the Tiaka Oilfield consisting of 6 genera. Three species of coral are the most dominant establish, namely Acropora formosa, Acropora nobilis, and Acropora grandis. Benthic organisms were found alienated into two groups: animal and plant groups. Benthic organisms in symbiosis with coral reef ecosystems in the oilfield consist of 11 benthic species consisting of 54 species.

\section{ACKNOWLEDGMENTS}

Thank you to the Joint Operating Body Pertamina-Medco E\&P Tomori Sulawesi (JOB Tomori) for facilitating the research implementation. The author also thanks to all parties who have contributed during the study.

\section{REFERENCES}

Ammar, M. S. A., El-Gammal, F., Nassar, M., Belal, A., Farag, W., El-Mesiry, G., El-Haddad, K., Orabi, A., Abdelreheem, A., \& Shaaban, A. (2013). Review: Current trends in coral transplantation - an approach to preserve biodiversity. Biodiversitas, 14(1), 43-53. https://doi.org/10.13057/biodiv/d140107

Anderson, K., Pratchett, M., \& Baird, A. (2012). Summer growth rates of corals at Lord Howe Island, Australia. Proceedings of the $12^{\text {th }}$ International Coral Reef Symposium, Cairns, Australia. https://researchonline.jcu.edu.au/22380/

Arini, D.I.I. (2013). The challenge and conservation efforts of Indonesian coral reefs [Indonesian]. Info BPK Manado, 3(2), 147-172. Retrieved from: https://www.forda-mof.org/

Babu, I. K. K., \& Sureshkumar, S. (2016). Survival and growth of transplanted coral fragment in lagoons of Lakshadweep with notes on fish aggregation. International Journal of Applied and Pure Science and Agriculture, 2(5), 19-25. Retrieved from: https://ijapsa.com/publishedpapers/volume-2/issue-5/survival-and-growth-of-transplanted-coral-fragments-in-lagoonsof-lakshadweep-with-notes-on-fish-aggregation.pdf

Bahri, B., Rudi, E., \& Dewiyanti, I. (2015). Coral reefs and macroinvertebrates condition in Ujong Pancu, Peukan Bada District, Aceh Besar [Indonesian]. Depik, 4(1), 1-7. http://dx.doi.org/10.13170/depik.1.1.2278

Burke, L., Selig, E., \& Spalding, M. (2002). Threatened coral reefs in Southeast Asia [Indonesian]. World Resources Institute.

Camp, E. F., Schoepf, V., Mumby, P. J., Hardtke, L. A., Rodolfo-Metalpa, R., Smith, D. J., \& Suggett, D. J. (2018). The future of coral reefs subject to rapid climate change: lessons from natural extreme environments. Frontiers in Marine Science, 5(4), 1-21. http://dx.doi.org/10.3389/fmars.2018.00004 
Edrus, I. N., Arief, S., \& Setyawan, I. E. (2010). Current state of Saleh Bay's reef health, Sumbawa: an aspect review of reef bottom substrates and reef fish diversity [Indonesian]. Jumal Penelitian Perikanan Indonesia, 16(2), 147-161. http://dx.doi.org/10.15578/jppi.16.2.2010.147-161

English, S,. Wilkinson, C., \& Baker, V. (1997). Survey manual for tropical marine resources. Second edition. Townsville: Australian Institute of Marine Science.

Fadli, N., Muchlisin, Z. A., Pratama, F. O., T R Mustari, Dewiyanti., Purnawan, S., El-Rahimi, S. A., Sofyan, H., Affan, M., and Siti-Azizah, M. N. (2019). The composition of coral reefs in Ulee Lheue Breakwater, Banda Aceh, Aceh, Indonesia. IOP Conf. Series: Earth and Environmental Science, 348, 1-5. http://dx.doi.org/10.1088/1755-1315/348/1/012077

Faqih, M. I., Effendy, M., \& Insafitri. (2016). The growth rate of coral Porites sp. on different substrates on Gili Rajeh Island, Sumenep Regency [Indonesian]. Proceedings of the National Ocean Seminar.

Giyanto., Abrar, M., Hadi, T. A., Budiyanto, A., Hafizt, M., Salatalohy, A., \& Iswari, M. (2017). Status of the coral reef in Indonesia 2017 [Indonesian]. Jakarta: LIPI Press.

Gomez, E. D., \& Yap, H. T. (1998). Monitoring Reefs Conditions. In: Kenchington, R. A. and B. E. T. Hudson (eds). Coral reef management handbook. UNESCO regional office for science and technology for South-East Asia. Jakarta.

Hadi, T. A., Giyanto., Prayudha, B., Hafizt, M., Budiyanto, A., \& Suharsono. (2018). Status of the coral reef in Indonesia [Indonesian]. Jakarta: LIPI Press.

Harahap, S. A., Syamsuddin, M. L., \& Purba, N. P. (2017). Coral reefs planting as the effort to increase the added value of the environment by the domed skeletal transplant method in Pangandaran [Indonesian]. Jurnal Pengabdian Kepada Masyarakat, 1(2), 68-71. http://jurnal.unpad.ac.id/pkm/article/view/16290

Insafitri \& Nugraha, W. A. (2006). Coral rate growth of Porites lutea [Indonesian]. IImu Kelautan, 11(1), 50-53. https://doi.org/10.14710/ik.ijms.11.1.50-53

Jiménez, C., Bassey, G., Segura, Á., \& Núñez, J. C. (2010). Characterization of the coral communities and reefs of two previously undescribed locations in the upwelling region of Gulf of Papagayo (Costa Rica). Revista Ciencias Marinas y Costeras, 2(1), 95-108. https://doi.org/10.15359/revmar.2.8

Khazali, M. (2007). Learning in the formation of the marine protected areas and management of Togean Islands National Park [Indonesian]. Prosiding MUNAS Terumbu Karang.

Lampe, I. (2018). Communication pattern in the social movements of the community around the Tiaka oil and gas mine [Indonesian]. Jurnal ASPIKOM, 3(5), 860-873. http://dx.doi.org/10.24329/aspikom.v3i5.334

Luthfi, O. M. (2016). Coral reef conservation using coral garden initiative in Sempu Island [Indonesian]. Journal of Innovation and Applied Technology, 2(1), 210-216. https://doi.org/10.24843/jmas.2019.v05.i01.p09

Manembu, I., Adrianto, L., Bengen, D., \& Yulianda, F. (2014). The abundance of coral fish in artificial reefs area of Ratatotok Waters, North Sulawesi [Indonesian]. Bawal, 6(1), 55-61. http://dx.doi.org/10.15578/bawal.6.1.2014.55-61

Mansyur, K., Rizal, A., Tis'in, M., Nurdin, M. S., \& Susanti, N. (2019). Growth and survival rate of coral transplantation at Tiaka Oil Field, Tolo Bay, Central Sulawesi [Indonesian]. Prosiding Simposium Nasional Kelautan dan Perikanan VI. Universitas Hasanuddin. Makassar. http://journal.unhas.ac.id/index.php/proceedingsimnaskp/article/view/7731

Muliawan, I., \& Firdaus, M. (2018). Economic value of coral reef ecosystem in The Kapoposang Marine Park Conservation, South Sulawesi [Indonesian]. Jurnal Sosial Ekonomi Kelautan dan Perikanan, 13(2), 133-142. http://dx.doi.org/10.15578/jsekp.v13i2.6866

Muqsit, A., Purnama, D., \& Ta'alidin, Z. (2016). The structure of the coral reef community in Pulau Dua, Enggano District, North Bengkulu Regency [Indonesian]. Jurnal Enggano, 1(1), 75-87. https://ejournal.unib.ac.id/index.php/jurnalenggano/article/viewFile/815/709

Panggabean, A. S., \& Setiadji, B. (2011). The bend of coral shape in leeward and winward areas at Pamegaran Island, Jakarta Bay [Indonesian]. Bawal, 3(4), 255-260. http://dx.doi.org/10.15578/bawal.3.4.2011.255-260

Ramadhan, A., Lindawati., \& Kurniasari, N. (2016). Economic value of coral reef ecosystem in the Wakatobi District [Indonesian]. Jurnal Sosial Ekonomi Kelautan dan Perikanan, 11(2), 133-146. http://dx.doi.org/10.15578/jsekp.v11i2.3834 
Rani, C. (2007). Climate changing: relation to coral reef [Indonesian]. Prosiding MUNAS Terumbu Karang.

Rani, C., Tahir, A., Jompa, J., Faisal, A., Yusuf, S., Werorilangi, S., \& Arniati. (2017). Successfullnes of coral reef rehabilitation by bleaching events in 2016 with transplantation technique [Indonesian]. Spermonde, 3(1), 13-19. http://journal.unhas.ac.id/index.php/jiks/article/view/2127

Renfro, B., \& Chadwick, N. E. (2017). Benthic community structure on coral reefs exposed to intensive recreational snorkeling. PLOS ONE, 12(9), 1-22. http://dx.doi.org/10.20956/jiks.v3i1.2127

Ruswahyuni \& Purnomo, P. W. (2009). Water quality gradation of coral reef at Seribu Island [Indonesian]. Jurnal Ilmiah Perikanan dan Kelautan, 1(1), 93-101. http://dx.doi.org/10.20473/jipk.v1i1.11704

Santoso, A. D., \& Kardono. (2008). Coral reef conservation and rehabilitation technology [Indonesian]. Jurnal Teknik Lingkungan, 9(3), 121-226. https://doi.org/10.29122/jtl.v9i3.465

Souhoka, J. (2009). Condition and diversity of hard coral at Nusalaut Island, Central Maluku [Indonesian]. Jurnal Perikanan, 11(1), 54-65. https://doi.org/10.22146/jfs.2985

Suharsono. (2008). Coral reef species in Indonesia [Indonesian]. Jakarta: LIPI Press.

Sukmara, A., Siahainenia, A. J., \& Rotinsulu, C. (2001). Guide of coral reef monitoring by community-based with manta tow method [Indonesian]. Coastal project. Special Issue. University of Rhode Island, Coastal Resources Center, Narragansett, Rhode Island, USA. Retrived from: https://www.crc.uri.edu/

Syakir, M., Mansyur, K., Yusuf, S., Syam, D., \& Aini, N. (2015). Learning management on coral reefs in the vicinity of oil drilling and Tiaka Gas Field, Tomori, Central Sulawesi [Indonesian]. Torani, 25(2), 88-95. http://journal.unhas.ac.id/index.php/torani/article/view/266

Tisín, M., \& Mansyur, K. (2016). A preliminary study of the coral reefs conditions with a different location in distances from the "production flares" of the Tiaka Oil Field [Indonesian]. Jumal Agrisains, 17(2), 78-84. http://jumal.untad.ac.id/jumal/index.php/AGRISAINS/artide/view/9971

Westmacott, S., Teleki, K., Wells, S., \& West, J. M. (2000). Management of bleached and critically damaged coral reefs [Indonesian]. IUCN, Gland, Switzerland and Cambridge, UK.

Wijaya, C. K., Komala, R., \& Giyanto. (2017). Condition, diversity, and growth forms of coral in Kayu Angin Genteng Island, Seribu Islands [Indonesian]. Bioma, 13(2), 108-118. https://doi.org/10.21009/Bioma13(2).7

Woodley, C.M., Bruckner, A. W., Galloway, S. B., McLaughlin, S. M., Downs, C. A., Fauth, J. E., Shotts, E. B., \& Lidie, K. L. (2003). Coral Disease and Health: A National Research Plan. National Oceanic and Atmospheric Administration, Silver Spring. http://epository.library.noaa.gov/

Yunus, B. H., Wijayanti, D. P., \& Sabdono, A. (2013). Acropora aspera coral transplantation with rope method in Awur Bay Waters, Jepara [Indonesian]. Buletin Oseanografi Marina, 2, 2228. https://doi.org/10.14710/buloma.v2i3.6947

Zhao, M., Zhang, H., Zhong, Y., Jiang, D., Yan, H., Zhang, H., Guo, P., Li, C., Liu, G., Yang, H., Chen, T., \& Wang, R. (2019). The status of coral reefs and its importance for coastal protection: a case study of Northeastern Hainan Island, South China Sea. Sustainability, 11, 1-13. https://doi.org/10.3390/su11164354 